\title{
COMPARATIVE BEHAVIOUR OF AGRICULTURAL BIOMASS RESIDUES DURING THERMOCHEMICAL PROCESSING
}

\author{
S.L. RINCON ${ }^{\star}$ \\ A. GOMEZ
}

Received: 30/12/11

Accepted: 09/03/12

Research Group on Biomass and Optimization of Thermal Systems - BIOT Department of Mechanical and Mechantronics Engineering, National University of Colombia, Bogotá (Colombia)

*to whom all correspondence should be addressed: e-mail: slrinconp@unal.edu.co

\section{ABSTRACT}

A study of the pyrolysis and gasification of biomass residues such as oil palm shells and fibers, coffee shells, sugarcane bagasse and beech wood is presented. All of them are abundant agroindustrial biomass residues in Latin American countries.

The characterization of the raw materials and products includes proximate analysis (water, ash and volatile matter contents) and ultimate analysis. Pyrolysis and gasification experiments are carried out in a thermobalance and in a pilot scale rotary kiln reactor. Both facilities are equipped with evolved gas analysis.

Pyrolysis experiments were carried out using nitrogen as carrier gas by heating up to a temperature of $950^{\circ} \mathrm{C}$. Gasification is performed using water vapour as reaction agent in a concentration of $70 \%$ $\mathrm{H}_{2} \mathrm{O}$ in nitrogen. The gasification temperature is set to $850^{\circ} \mathrm{C}$.

All wastes show similar behavior during pyrolysis in the thermobalance with the main mass loss at temperatures below $550{ }^{\circ} \mathrm{C}$. The solid fraction varied from $18 \%$ for sugarcane bagasse to $27 \%$ for oil palm shells and the gas fraction from $18 \%$ for oil palm shells to $22 \%$ for sugarcane bagasse. The main evolved gases are $\mathrm{CO}_{2}(9-12 \%), \mathrm{CO}(3.5-7.5 \%)$ and $\mathrm{CH}_{4}(1.6-3 \%) . \mathrm{H}_{2}$ was also found but in a very small fraction $(0.5-0.7 \%)$ (all fractions are referred to the initial dry mass). The heating value of the pyrolysis products from the experiments in the thermobalance of the different wastes presented small variations with a mean value of $6.5 \mathrm{MJ} \mathrm{kg}^{-1}$ for the evolved gas, $20 \mathrm{MJ} \mathrm{kg}^{-1}$ for the tar and $19 \mathrm{MJ} \mathrm{kg}^{-1}$ for the solid residual.

The presence of secondary reactions in the rotary kiln affects considerably the amount of gas and tar in the products. The higher heating value of the evolved gases varies between 17 and19 $\mathrm{MJ} \mathrm{kg}^{-1}$.

The obtained results allow a possible further technological use of these materials as a cheap renewable energy source in countries where these materials can be found.

KEYWORDS: Pyrolysis, Gasification, thermochemical processing, agroindustrial residues, Activated carbon.

\section{INTRODUCTION}

Agroindustrial biomass residues are a potential renewable energy source. Their physical and chemical properties make them suitable for their conversion using thermochemical processes such as pyrolysis and gasification. Oil palm shells and fibers, sugar cane bagasse and coffee shells are important agroindustrial biomass residues in Colombia, which find application as fuel in boilers and heaters in industrial processes. One part of these residues remain however as waste, generating environmental problems.

The study of the pyrolysis process is fundamental; through this process combustible solid, liquid and gaseous products are generated. Gasification consists in the reaction of the obtained solid material from the pyrolysis (char) with a reaction agent, which can be $\mathrm{O}_{2}, \mathrm{H}_{2} \mathrm{O}, \mathrm{CO}_{2}$ and $\mathrm{H}_{2}$. After treatment 
the combustible gas obtained can be used in internal combustion engines or microturbines for the production of electricity.

\section{MATERIALS AND METHODS}

\subsection{Characterization of the raw materials}

Oil palm shells, oil palm fibers, coffee shells and sugar cane bagasse were characterized in terms of ultimate and proximate analysis and the determination of the heating value. Water, ash and volatile matter contents of the samples were determined by DIN 51718, DIN 51719 and DIN 51729, respectively. An additional determination of ash content at $550{ }^{\circ} \mathrm{C}$ was also performed. $\mathrm{C}, \mathrm{H}$ and $\mathrm{N}$ contents were measured by an elementary analyzer Model 1106, from Carlo Erba Instruments. The sulphur content was assumed negligible (Wiest, 1998). The oxygen content was calculated by difference. The higher heating value was calculated with the Boie correlation (Boie, 1957) from the elemental analysis.

\subsection{Pyrolysis and partial gasification experiments}

Pyrolysis and gasification experiments were carried out in a thermobalance and in a pilot scale rotary kiln.

For the themogravimetric analysis the experimental facility shown in Figure 1 was used. The weight loss of the samples was measured by a precision balance with an accuracy of $0.1 \mathrm{mg}$. The composition of the evolved gas $\left(\mathrm{CO}_{2}, \mathrm{CO}, \mathrm{CH}_{4}\right.$ and $\left.\mathrm{H}_{2}\right)$ was determined continuously by means of gas analyzers.

Experimental conditions with minimal influence of heat and mass transfer limitations were identified. A rapid evacuation of the evolved volatile products from the biomass sample was ensured with a flow of 2 I $\mathrm{min}^{-1}$ (STP). For pyrolysis $\mathrm{N}_{2}$ was used as carrier gas. Gasification experiments were carried out with water vapour as reaction agent.

Pyrolysis experiments until $950{ }^{\circ} \mathrm{C}$ with a heating rate of $10 \mathrm{~K} \mathrm{~min}^{-1}$, a bed height of $10 \mathrm{~mm}$ and a particle size $x<0.5 \mathrm{~mm}$ were performed. The mass of each sample depends on its density for the constant bed height; the values are shown in Table 3. The yields of char and evolved gas fraction were measured and the yield of tar and water was calculated by difference. The fraction of water in tar is calculated from the values reported by (Rincón, 2000) and (Gómez, 2006).

For gasification experiments water vapour was used as reaction agent. Its concentration was established through a water vapour saturator at $70 \% \mathrm{H}_{2} \mathrm{O}-30 \% \mathrm{~N}_{2}$. Three different experimental procedures were used:

A. Biomass is put into the reactor and heated at $3 \mathrm{~K} \mathrm{~min}^{-1}$ under nitrogen atmosphere until the gasification temperature of $850{ }^{\circ} \mathrm{C}$ is reached. The nitrogen flow is then switched to a mixture of $70 \% \mathrm{H}_{2} \mathrm{O}-30 \% \mathrm{~N}_{2}$ and is maintained by constant temperature until total gasification of the sample.

B. The heating of the sample is carried out under a $70 \% \mathrm{H}_{2} \mathrm{O}-30 \% \mathrm{~N}_{2}$ atmosphere. All other conditions remain the same as for the first experimental procedure (A).

C. Chars of oil palm shells, coffee shells and beech wood are put into the reactor.All other conditions remain the same as for the first experimental procedure $(A)$.

A simplified schema of the rotary kiln facility is shown in Figure 2. The operation of the rotary kiln is semi-continuous with a screw conveyor transporting biomass from a store tank into the reaction zone. The solid residence time $(t)$ is determined in cold runs by varying the inclination angle and the speed depending of the feedstock properties. At the end of the kiln the solid product is separated from the gas, the condensable oils and the water steam which subsequently pass a particulate filter and are then cooled. Process control consists of the temperature and pressure measurements and continuous determination of the composition of the produced gases by gas analysers and gas chromatography. The conditions of the experiments performed in the rotary kiln are shown in Table 1. The particle size used was for all experiments between 2 and $4 \mathrm{~mm}$. One pyrolysis experiment and four partial gasification experiments with variation of the water vapour concentration were performed. 


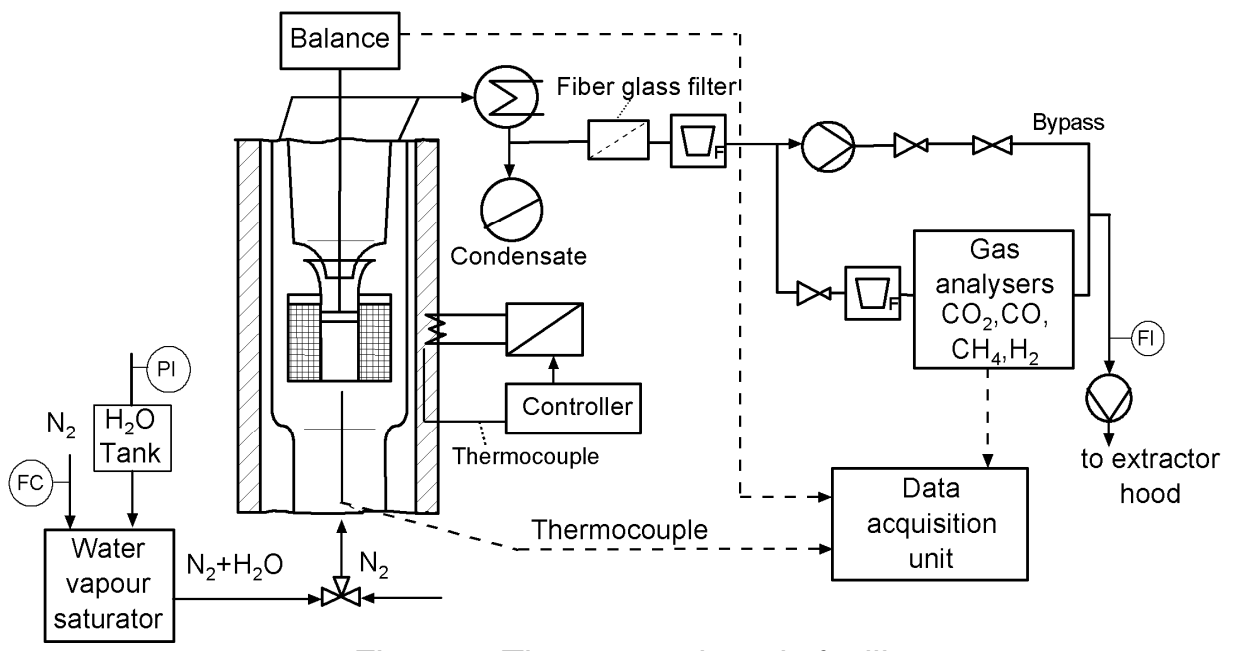

Figure 1. Thermogravimetric facility

Table 1. Experimental conditions for the pyrolysis and gasification of oil palm shells in a rotary kiln

\begin{tabular}{|c|c|c|c|c|}
\hline Name & $\begin{array}{c}\mathrm{T} \\
\left({ }^{\circ} \mathrm{C}\right)\end{array}$ & $\begin{array}{c}\mathrm{t} \\
(\min )\end{array}$ & $\begin{array}{l}\text { Output } \\
\left(\mathrm{g} \mathrm{min}^{-1}\right)\end{array}$ & Atmosphere \\
\hline DROS3P & 850 & 55 & 24 & $\mathrm{~N}_{2}$ \\
\hline DROS2A & 850 & 55 & 22 & $\mathrm{~N}_{2}-\mathrm{H}_{2} \mathrm{O}$ (water in material $11,6 \%$ ) \\
\hline DROS1A & 850 & 105 & 9 & $\mathrm{~N}_{2}-\mathrm{H}_{2} \mathrm{O}$ (water in material $11,6 \%$ ) \\
\hline DROS4A & 850 & 105 & 16 & $\mathrm{~N}_{2}-\mathrm{H}_{2} \mathrm{O}$ (water in material $11,6 \%+10,00 \mathrm{~g} \mathrm{~min}^{-1}$ ) \\
\hline DROS7A & 850 & 105 & 13,7 & $\mathrm{~N}_{2}-\mathrm{H}_{2} \mathrm{O}$ (water in material $11,6 \%+29,50 \mathrm{~g} \mathrm{~min}^{-1}$ ) \\
\hline
\end{tabular}

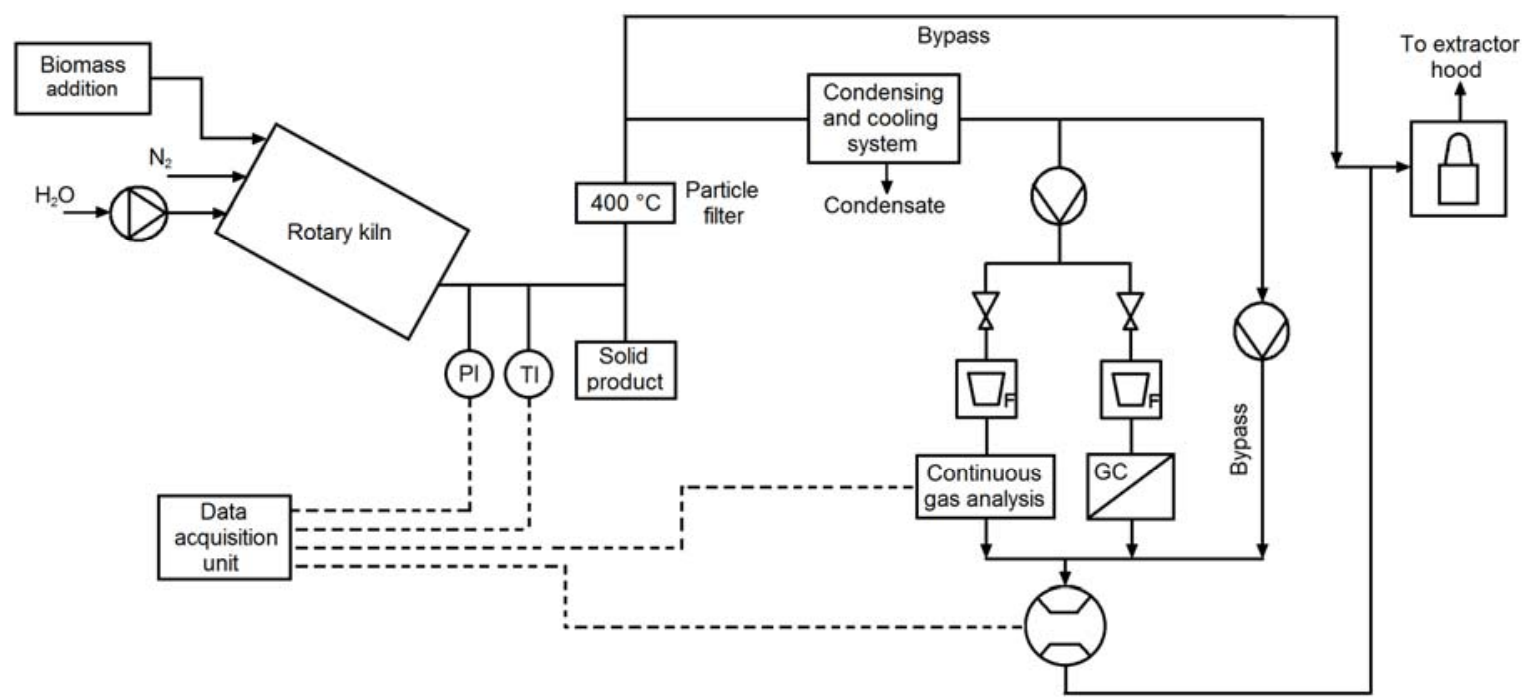

Figure 2. Rotary kiln facility

\section{RESULTS AND DISCUSSION}

The results of the characterization of the biomass residues are shown in Table 2. All samples show a high content of volatile matter and similar water content, the last one depends on the specific ambient conditions and can be as high as $35 \%$ for oil palm shells. Sugar cane bagasse has a very high ash content compared with the other biomasses. The $\mathrm{C}, \mathrm{N}, \mathrm{H}$ and $\mathrm{O}$ contents are very similar for all biomasses. The higher heating value of the biomasses varies between $21.1 \mathrm{MJ} \mathrm{kg}^{-1}$ for oil palm shells and $19.0 \mathrm{MJ} \mathrm{kg}^{-1}$ for coffee shells. 
Table 2. Characterization of the raw materials

\begin{tabular}{|c|c|c|c|c|}
\hline Sample & $\begin{array}{l}\text { Oil } \\
\text { palm } \\
\text { shells }\end{array}$ & $\begin{array}{l}\text { Oil palm } \\
\text { fibers }\end{array}$ & $\begin{array}{l}\text { Coffee } \\
\text { shells }\end{array}$ & $\begin{array}{l}\text { Sugar } \\
\text { cane } \\
\text { bagasse }\end{array}$ \\
\hline \multicolumn{5}{|c|}{ Proximate analysis (\%) } \\
\hline $\mathrm{VM}_{\mathrm{df}}$ & 77.9 & 77.9 & 81.3 & 79.6 \\
\hline$a_{d f}\left(550^{\circ} \mathrm{C}\right)$ & 1.6 & 3.5 & 1.2 & 8.1 \\
\hline$a_{d f}\left(815^{\circ} \mathrm{C}\right)$ & 1.6 & 3.5 & 0.9 & 6.4 \\
\hline w & 11.2 & 10.5 & 10.1 & 15.0 \\
\hline \multicolumn{5}{|c|}{ Ultimate analysis (\%) } \\
\hline $\mathrm{C}_{\text {daf }}$ & 55.7 & 49.6 & 50.3 & 53.1 \\
\hline $\mathrm{H}_{\mathrm{daf}}$ & 5.0 & 5.5 & 5.3 & 4.7 \\
\hline$N_{\text {daf }}$ & 0.4 & 2.4 & 0.6 & 0.5 \\
\hline $\mathrm{O}_{\text {daf }}{ }^{*}$ & 38.9 & 42.5 & 43.8 & 41.7 \\
\hline \multicolumn{5}{|c|}{ Higher heating value $\left(\mathrm{MJ} \mathrm{kg}^{-1}\right)$} \\
\hline $\mathrm{HHV}$ & 21.1 & 19.3 & 19.0 & 19.5 \\
\hline
\end{tabular}

\subsection{Pyrolysis and gasification experiments in the thermobalance}

The mass loss of the biomass and the formation of gas and volatile matter (tar + water) during the pyrolysis of oil palm shells at $10 \mathrm{~K} \mathrm{~min}^{-1}$ and a final temperature of $950{ }^{\circ} \mathrm{C}$ is shown in Figure 3 . The main pyrolysis reactions take place until temperatures of approx. $500{ }^{\circ} \mathrm{C}$. After that a very small conversion is observed. The main evolved gases are $\mathrm{CO}_{2}$ and $\mathrm{CO}$ and in a lesser extent $\mathrm{CH}_{4}$ and $\mathrm{H}_{2}$. The formation of $\mathrm{CO}_{2}$ and $\mathrm{CO}$ takes place in the same temperature interval as the main mass loss of the sample. $\mathrm{CH}_{4}$ and $\mathrm{H}_{2}$ are evolved at higher temperatures.

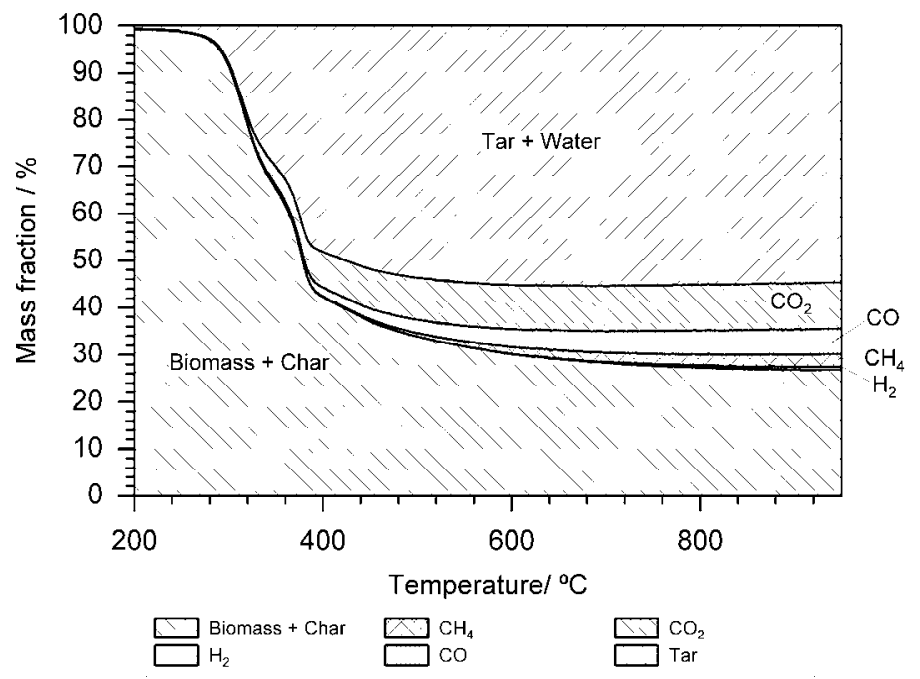

Figure 3. Mass loss and product formation during pyrolysis of oil palm shells in a thermobalance at $10 \mathrm{~K} \mathrm{~min}^{-1}$

Table 3 presents the mass balance for the pyrolysis products for the residual biomasses. Oil palm shells have the highest char and lowest tar yield. Oil palm fibers show the highest tar formation. The water yield of the table corresponds to the water formed during the pyrolysis process without taking into account the initial biomass content of the samples. Sugar cane bagasse has the highest gas formation followed by coffee shells, oil palm shells and oil palm fibers.

The higher heating value of the pyrolysis products obtained through pyrolysis until $550{ }^{\circ} \mathrm{C}$ according to the ISO norm 647 "Brown Coal and Lignites - Determination of the Yields of Tar, Water, Gas and Coke Residues by Low Temperature Distillation" is determined. The values vary between 33.8 and $34.4 \mathrm{MJ} \mathrm{kg}^{-1}$ for the char, 6.2 and $7.6 \mathrm{MJ} \mathrm{kg}^{-1}$ for the gas and 16.5 and $22.9 \mathrm{MJ} \mathrm{kg}^{-1}$ for the tar (Gómez, 2008). 
Table 3. Used mass and mass balance during pyrolysis in a thermobalance of different biomass residues at $10 \mathrm{~K} \mathrm{~min}^{-1}$

\begin{tabular}{ccccc}
\hline Sample & $\begin{array}{c}\text { Oil palm } \\
\text { shells }\end{array}$ & $\begin{array}{c}\text { Oil palm } \\
\text { fibers }\end{array}$ & $\begin{array}{c}\text { Coffee } \\
\text { shells }\end{array}$ & $\begin{array}{c}\text { Sugar cane } \\
\text { bagasse }\end{array}$ \\
\hline Biomass (g) & 4.3 & 3.2 & 4.3 & 1.3 \\
\hline Char (\%) & 26.8 & 24.2 & 24.1 & 20.3 \\
Gas (\%) & 18.5 & 14.9 & 20.3 & 21.8 \\
Tar $^{1}(\%)$ & 21.9 & 46.2 & 34.5 & 25.3 \\
Water $^{1,2}(\%)$ & 32.8 & 14.6 & 21.1 & 34.9 \\
\hline${ }^{1}$ The sum of the amount of tar and water content is calculated as difference \\
${ }^{2}$ The fraction of water in tar is calculated from the values reported by (Rincón, 2000)
\end{tabular}

Figure 4 shows the mass fractions of the evolved gases during the pyrolysis process for different biomasses. All samples show a similar behaviour with the main formation of $\mathrm{CO}_{2}$ followed by $\mathrm{CO}$, $\mathrm{CH}_{4}$ and $\mathrm{H}_{2}$.

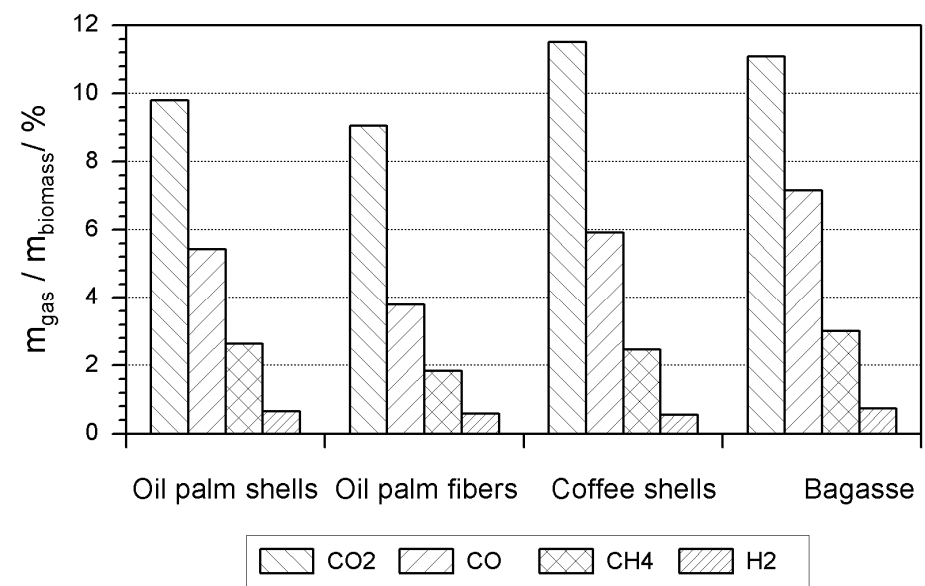

Figure 4. Evolved gas composition for different biomasses during pyrolysis in a thermobalance at $10 \mathrm{~K} \mathrm{~min}^{-1}$ and final temperature $950^{\circ} \mathrm{C}$

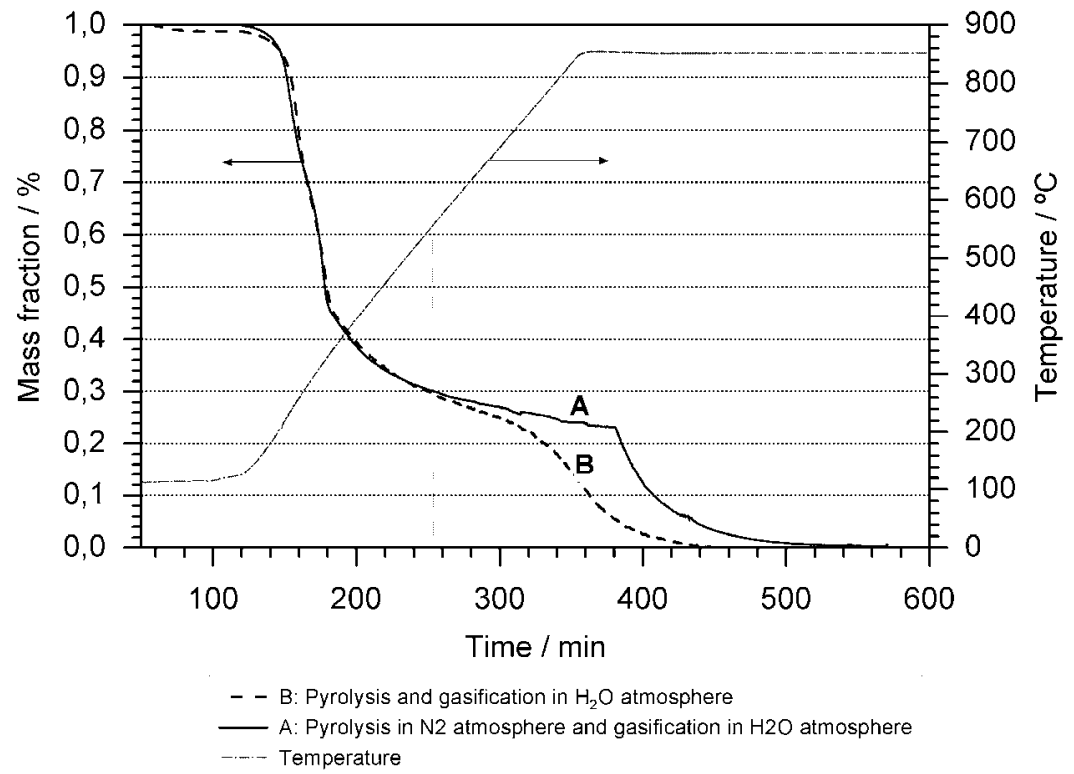

Figure 5. Mass loss during pyrolysis and gasification of oil palm shells in a thermobalance

Figure 5 shows the results of the gasification experiments according to procedures $A$ and $B$ described above. Both processes proceed in the same way until reaching a temperature of $550{ }^{\circ} \mathrm{C}$, 
so the presence of water vapor doesn't affects the primary reactions of the pyrolysis process. After this temperature, for procedure $B$, begins the gasification of the char, resulting in a shorter reaction time needed for complete conversion compared to process $A$ in which the gasification step begins only after reaching the gasification temperature and switching to the reaction agent.

In Figure 6 the results of the gasification of chars according to procedure $C$ are presented. The part of the process showed corresponds to the gasification step of procedure A (see Figure 6). Oil palm shells show a different behaviour than that of beech wood and coffee shells. The gasification time is three times longer than for the other two biomasses. This can be due to differences in the physical structure of the original biomasses. Oil palm shells are very hard and resistant while the beech wood and coffee shells are soft and fragile. For chars of this last two biomasses the curves of mass loss show a linear dependence with time until conversions higher than $85 \%$ while for oil palm shells this linear behaviour is only for conversions bellow $40 \%$. This can be atributed to a higher influence of the physical structure of the solid for gasification of oil palm shells.

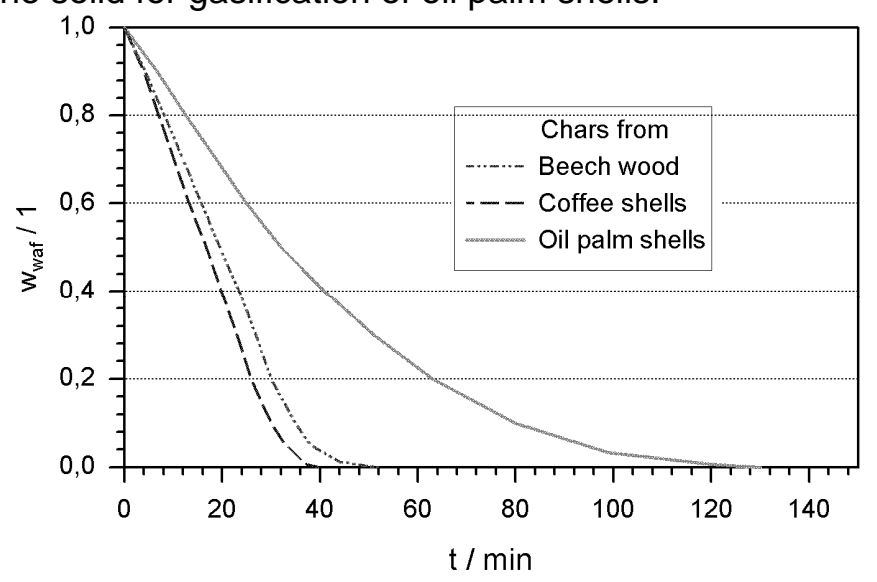

Figure 6. Mass loss during gasification in a thermobalance of chars from different biomasses at $850{ }^{\circ} \mathrm{C}$ and $70 \% \mathrm{H}_{2} \mathrm{O}$

\subsection{Pyrolysis and gasification experiments in the rotary kiln}

The mass fractions of the products for the experiments carried out in the rotary kiln, according to Table 1, are shown in Figure 7. Making a comparison of the results of the pyrolysis experiment DROS3P with the pyrolysis in the thermobalance (see Table 3) a higher gas fraction and less water and tar fractions are obtained. This can be attributed to the occurrence of secondary reactions in the gas phase that leads to the formation of more gas thought tar decomposition and water vapour reactions with the components of the gas fraction. The solid fraction remains at almost the same level.

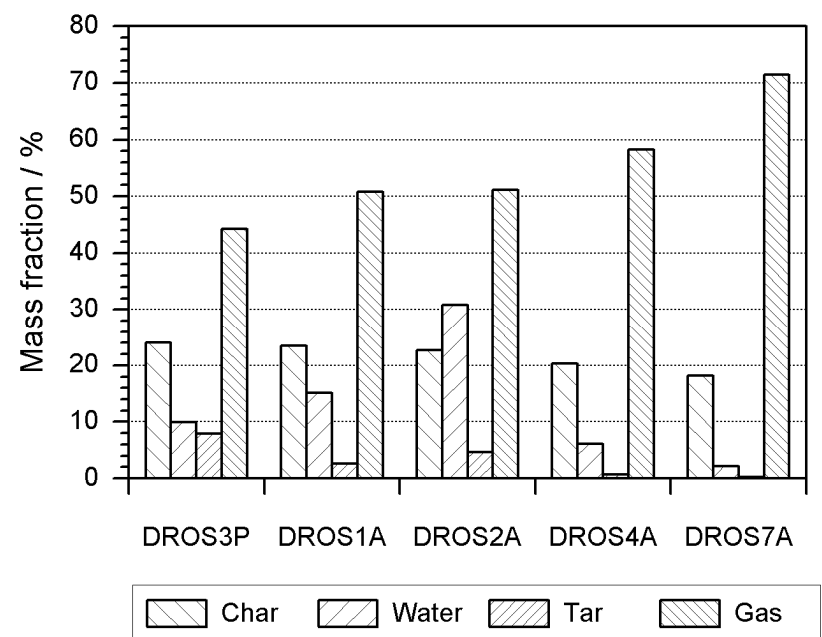

Figure 7. Mass fractions for the pyrolysis and gasification of oil palm shells in a rotary kiln The influence of the water vapour concentration can be observed in the experiments DROS1A, DROS4A and DROS7A. With higher water vapour concentrations a higher gas fraction and a lowest 
tar and water content can be observed. This is mainly due to the gasification reactions with water vapour.

The higher heating value of the produced gases is shown in Table 4. This is $18.13 \mathrm{MJ} \mathrm{kg}^{-1}$ for pyrolysis and varies between 17.6 and $18.6 \mathrm{MJ} \mathrm{kg}^{-1}$. This value is considerable higher than the usual value of the gas obtained through gasification with air, which varies between 5.7 and 8.6 (Bridgwater, 1995).

\section{CONCLUSIONS}

Different types of biomass residues present similar behavior during pyrolysis, which is characterized by a high mass loss until $550{ }^{\circ} \mathrm{C}$. The main evolved gases are $\mathrm{CO}_{2}, \mathrm{CO}$ followed by $\mathrm{CH}_{4}$ and $\mathrm{H}_{2}$. The product composition of all samples is also very similar for char and gas: 20 to $26 \%$ char, 18 to $22 \%$ gas. The tar and water fractions show a big variation (21 to $46 \%$ tar and 14 to $35 \%$ water), nevertheless the final amount to tar + water is also very similar. As the fractions of tar and water are taken from a literature source it is advisable to perform this measurement.

The presence of water vapour doesn't affect the course of the primary pyrolysis reactions until temperatures above $550{ }^{\circ} \mathrm{C}$, at this level gasification of the obtained char begins. The reaction time for total gasification of chars from oil palm shells is three times longer than for coffee shells and beech wood. This can be attributed to differences in the physical structure of the raw materials.

In the rotary kiln the presence of secondary pyrolysis and gasification reaction play an important role in the final distribution of the products. The higher the water vapour concentration the higher the gas fraction and the lower the tar and water fractions.

\section{REFERENCES}

Antal M.J., (1982) Biomass Pyrolysis: A review of the literature Part 1 - Carbohidrate pyrolysis, In: Advances in Solar Energy, Boer, K.W. and Duffie, J.A., (Eds), American Solar Energy Society, New York.

Boie W., (1957), Vom Brennstoff zum Rauchgas (From fuel to flue gas), Teubner, Leipzig (in German).

Bridgwater A., (1995), The technical and economic feasibility of biomass gasification for power generation, Fuel, 74, $631-653$.

Gómez A., Klose W., Rincón S., (2008), Pirólisis de Biomasa: Cuesco de Palma (Biomass pyrolysis: Oil palm shells), Kassel University Press, Kassel (in Spanish).

Gómez A., (2006), Zur Teilvegasung von Biomasse in a Rotary Kiln Reaktor (Partial gasification in a rotary kiln reactor). PhD Thesis, University of Kassel (in German).

Rincón S., (2000), Herstellung von Aktivkohle aus Biogenen Reststoffe zum Einsatz in der Rauchgasreinigung, (Production of activated carbon from biological materials for using in flue gas cleaning), Report, Institute for Thermal Engineering, University of Kassel (in German).

Wiest W., (1998), Zur Pyrolyse von Biomasse im Drehrohrreaktor, (Biomass pyrolysis in a rotary kiln reactor), PhD Thesis, University of Kassel (in German). 